\title{
The thiol-disulphide homeostasis in patients with acute pancreatitis and its relation with other blood parameters
}

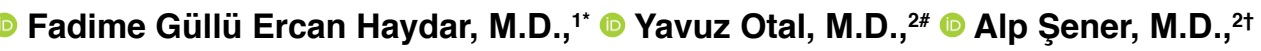

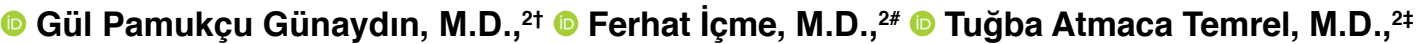 \\ (1) Pervin Baran, M.D., ${ }^{3 \S}$ () Özcan Erel, M.D. ${ }^{4 \pi}$
}

\begin{abstract}
${ }^{1}$ Department of General Surgery, Atatürk Training and Research Hospital, Ankara-Turkey
${ }^{2}$ Department of Emergency Medicine, Atatürk Training and Research Hospital, Ankara-Turkey

${ }^{3}$ Department of Medical Biochemistry, Atatürk Training and Research Hospital, Ankara-Turkey

${ }^{4}$ Department of Medical Biochemistry, Yıldırım Beyazıt University Faculty of Medicine, Ankara-Turkey
\end{abstract}

\begin{abstract}
BACKGROUND: Acute pancreatitis is a common disease seen in emergency departments because of abdominal pain. The present study aims to evaluate the relation between measurements of thiol-disulfide parameters in patients diagnosed with acute pancreatitis and other blood parameters.
\end{abstract}

METHODS: A total of 56 (56\%) patients, who were admitted to the emergency department, and 44 (44\%) healthy volunteers participated in this study. A total of 100 samples were taken from the participants. Detailed blood samples were taken from the patients at the time of arrival at the hospital. The thiol-disulfide level in serum was examined using a brand new method that was developed by Erel and Neşelioğlu in the venous blood samples of the patients who were diagnosed with acute pancreatitis during the admission. The data were evaluated in the computer medium.

RESULTS: Gallstones were defined as the etiology of AP in 41 patients (73.2\%); in one patient, hypertriglyceridemia (I.7\%); in four patients, alcohol use (7.1\%), and idiopathic 10 patients (17.8\%). While the blood thiol levels were low, the disulfide levels were high at a significant level. No statistically significant relations were detected between the amylase, lipase, neutrophil lymphocyte ratio (NLR), which are other blood parameters, and thiol-disulfide balance parameters.

CONCLUSION: The disruption of the thiol-disulfide balance may play a role in the pathogenesis of acute pancreatitis. In acute pancreatitis, since the thiol level is decreased in the blood, administration of the complementary therapies for this thiol deficiency may contribute to the treatment of the disease.

Keywords: Acute pancreatitis; oxidative stress; thiol-disulphide homeostasis.

\section{INTRODUCTION}

Thiols, in other words, mercaptans, are in -SH group. ${ }^{[1]}$ Generally, the plasma thiol pool is made up of thiols like albumin and low-molecular-weight cysteinylglycine, cysteine (Cys), homocysteine, glutathione and $\gamma$-glutamylcysteineprotein. ${ }^{[2]}$
Thiol-disulphide homeostasis is extremely important. Thiol/ Disulphide Ratio (TDR) is very important in the detoxification process. In previous studies, the findings showed that TDR had several effects on antioxidant protection, signal transduction, enzymatic regulation, apoptosis and cellular signal mechanisms. ${ }^{[3,4]}$

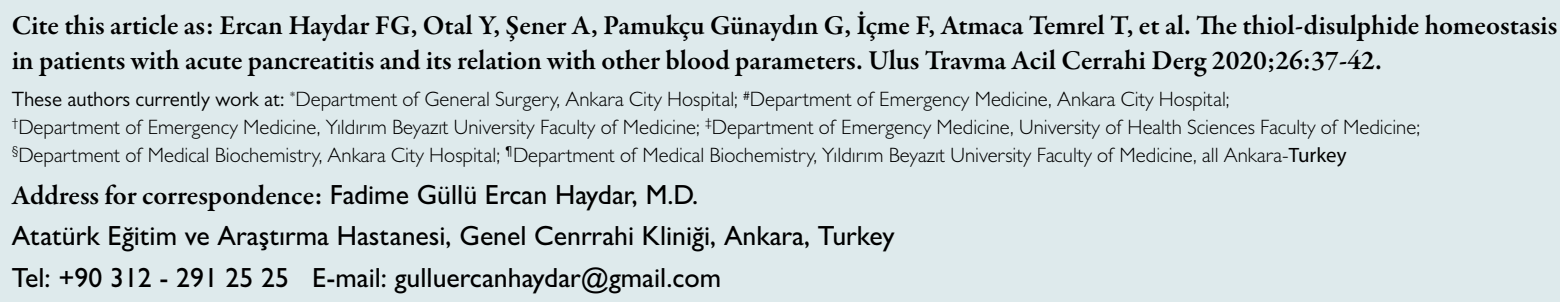


In some diseases, the Thiol-Disulphide Ratio was examined. This ratio was measured unilaterally until 2014 , and with the help of the new method that was developed by Erel and Neşelioglu, ${ }^{[5]}$ it is, nowadays, possible to measure it bilaterally. ${ }^{[6]}$

Acute pancreatitis (AP) is rare in clinical practice and its prevalence is approximately 80 per 100.000 people. ${ }^{[7,8]}$ Severe AP occurs with persistent organ failure. The mortality and morbidity rates of severe AP are also high. ${ }^{[9,10]}$ In recent years, a moderately severe AP has been reported as consisting of patients with transient organ failure or local/systemic complications without persistent organ failure. ${ }^{[9,11]}$

In this study, we aim to examine the thiol/disulphide homeostasis parameters, which constitute homeostasis occurring in the maintenance of many physiological mechanisms that are necessary for organisms and patients with AP.

\section{MATERIALS AND METHODS}

This study was approved by the ethical board of Yildirim Beyazit University (date: 03.12.2014, no: 208). A total of 56 (56\%) patients, who were admitted to the emergency department, and $44(44 \%)$ healthy volunteers participated in this study. A total of 100 samples were taken from the participants. AP diagnosis was considered as detection of two of the three necessary diagnosis criteria, which are (a) abdominal pain consistent with AP; (b) serum lipase or amylase levels being higher than three times the maximum limit of normal; and (c) the common findings obtained with abdominal imaging methods. ${ }^{[7]}$

The exclusion criteria in the present study were patients who had chronic pancreatitis, malignant illnesses, renal failures, liver failures, heart failures, myocardial infarctions, rheumatic illnesses, psychiatric patients, and patients who had immunosuppressive disorders. The reason for this exclusion was that these diseases or conditions might affect the thiol/disulphide homeostasis.

Detailed blood samples were taken from the patients at admission. The thiol-disulphide ratio was examined with a brand-new method that was developed by Erel and Neşelioğlu ${ }^{[5]}$ at the admission of the patients who were diagnosed with acute pancreatitis.

\section{Thiol-Disulphides Homeostasis Parameters Measurement}

Thiol/Disulphide Homeostasis tests were measured using an automated spectrophotometric method described by Erel and Neselioglu. For short, disulphide bonds were first reduced to form free functional thiol groups with sodium borohydride. Unused reductant sodium borohydride was consumed and removed with formaldehyde to prevent the reduction of DTNB (5,5'-dithiobis-(2-nitrobenzoic) acid), and all of the thiol groups, including reduced and native thiol groups, were determined after the reaction with DTNB. Half of the difference between the total thiols and native thiols provides the dynamic disulphide amount. After the determination of native and total thiols, disulphide amounts, disulphide/total thiol percent ratios (SS/SH+SS), disulphide/native thiol percent ratios $(\mathrm{SS} / \mathrm{SH})$ and native thiol/total thiol percent ratios $(\mathrm{SH} / \mathrm{SH}+\mathrm{SS})$ were calculated. ${ }^{[5]}$

\section{Measurement of the IMA (Ischemia-Modified Albumin)}

Measurement of IMA levels was obtained using venous blood samples on admittance within one hour. Specimens were stored for 30 minutes at room temperature and then centrifuged at $3500 \mathrm{rpm}$ for five minutes. Latter samples were transferred to Eppendorf tubes and stored at $-80^{\circ} \mathrm{C}$ until analysis. Albumin Cobalt Binding Test was used to detect the presence of Ischemia Modified Albumin (IMA). This test was performed by adding $50 \mathrm{~mL} 0.1 \%$ cobalt (II) chloride $(\mathrm{CoCl} 2,6 \mathrm{H} 2 \mathrm{O})$ (Sigma-Aldrich Chemie $\mathrm{GmbH}$ Riedstrasse 2, Steinheim, Germany) to the patient serum. After mixing, followed by 10 minutes of incubation to allow for albumin cobalt binding, $50 \mathrm{~mL} 1.5 \mathrm{mg} / \mathrm{mL}$ dithiothreitol was added. After mixing, followed by two minutes of incubation, $1.0 \mathrm{~mL}$ of a $0.9 \%$ sodium chloride solution was added to reduce the binding capacity. The blank was prepared similarly with distilled water instead of dithiothreitol. The absorbance of samples was measured at $470 \mathrm{~nm}$ using a spectrophotometer. The results were expressed as absorbance units (ABSU). ${ }^{[12]}$

\section{Ferroxidase Measurement}

Ferroxidase levels were measured using the method described by Erel O.T. This method is automated, colorimetric and based on the enzymatic oxidation of ferrous ion to ferric ion. The results were expressed in units per liter serum. ${ }^{[3]}$

Albumin, urea and creatinine tests were performed using Roche cobas $\mathrm{c50l}$ device using commercial kits of Roche.

Neutrophil, lymphocyte and platelet levels were measured using the Sysmex hematology device.

\section{Statistical Analyses}

The data were analyzed with the SPSS for Windows 16.0 Package Program. Firstly, descriptive statistics were given. The ratio comparisons in $2 \times 2$-eyed tables were performed with the Chi-Square test. The normality analysis of the continuous data was carried out with the Kolmogorov-Smirnov Test, and it was accepted as a result of the test that the data with a value of $p<0.05$ were not distributed normally. The Independent Samples t-test was employed for the data that showed the normal distribution in the comparisons made between two groups, and the Mann-Whitney U-test was employed for the data that did not show normal distribu- 
tion. The Spearman Correlation Test was employed for the analysis in the analysis of the data that were not normally distributed, and the Pearson Correlation Test was employed in the normally distributed data. The P-value was employed for statistical significance, and the results that were $\mathrm{p}<0.05$ were considered to be statistically significant.

As a result of the correlation analyses, no parameters were determined that had a correlation with the hospitalization time at a significant level. NLR had a weak correlation with amylase $(p=0.018$, rho: 0.333$)$ and lipase $(p=0.031$, rho: 0.306). No relations were detected between the thiol/disulphide homeostasis parameters and amylase and/or lipase.

\section{RESULTS}

The study group consisted of 56 (56\%) patients, and 44 (44\%) healthy volunteers applying to the emergency department. A total of 100 samples were taken from the participants. The mean age of the Control Group was 64 (Min-max: 21-80), and the mean age of the Study Group was found to be 57 (Min-max: 18-92). There were no differences between the two groups concerning age distribution at a statistically significant level. In the Control Group, the male gender was $38.6 \%$, and in the Study Group, it was 39.3\%. This difference was not found to be statistically significant (Table I).
The AP etiology was gallstones in $4 \mathrm{I}$ of the patients (73.2\%), hypertriglyceridemia in one patient (I.7\%), alcohol use in four patients (7.1\%), and was idiopathic in 10 patients (17.8\%).

The in-hospital mortality was determined as $1.8 \%$ (I case) in the Study Group. The 28-day mortality was also determined to be I.8\% (I case). The mean hospitalization was determined as five days (min-max: I-4I; IQR:3) (6.05 days on average).

According to the Balthazar Classification and the CTSI (Computed Tomography Severity Index), 32 patients in the Study Group had AP, 32 had mild AP (0-4 points), 20 had moderatesevere AP (4-6 points), and four patient had severe AP (7-10 points). ${ }^{[14]}$

The hematologic and biochemical parameters, thiol/disulphide homeostasis parameters, IMA and ferroxidase average and median values and the statistical analysis of the differences of the Patient and Control Group are given in Table I. The findings showed that all of the creatinine, neutrophil, neutrophil/lymphocyte ratio, thiol/disulphide homeostasis parameters, IMA and ferroxidase values were different at a statistically significant level between the groups (Figs. I-3). In the Patient Group, the neutrophil, neutrophil/lymphocyte ratio, disulphide and IMA were higher at a significant level and the creatinine, NT, TT, index-I, and ferroxidase were lower at a significant level (Table I).

Table I. Biochemical and hematological parameters in patient and control groups

\begin{tabular}{|c|c|c|c|c|c|c|c|c|c|c|c|c|c|}
\hline & \multicolumn{12}{|c|}{ Acute pancreatit patient / Control group } & \multirow[t]{3}{*}{$\mathbf{p}$} \\
\hline & \multicolumn{6}{|c|}{ Control } & \multicolumn{6}{|c|}{ Patient } & \\
\hline & Mean & SD & Min & Med & Max & $\begin{array}{c}95 \% \mathrm{Cl}^{*} I \\
\mathrm{IQR}^{* *}\end{array}$ & Mean & SD & Min & Med & Max & $\begin{array}{c}95 \% \mathrm{Cl}^{*} I \\
I^{*} \mathrm{R}^{* *}\end{array}$ & \\
\hline Albumin* & 4.38 & 0.36 & 3.74 & 4.32 & 5.06 & $4.27-4.49$ & 4.31 & 0.42 & 3.4 & 4.31 & 5.22 & $4.26-4.47$ & 0.371 \\
\hline Ure ${ }^{* *}$ & 35.2 & 11.8 & 18.2 & 34 & 66.7 & 19.0 & 32.1 & 14.7 & 13 & 27.4 & 82 & 12.0 & 0.066 \\
\hline Creatinin $^{* *}$ & 0.9 & 0.16 & 0.56 & 0.95 & 1.28 & 0.22 & 0.9 & 0.81 & 0.3 & 0.8 & 6.5 & 0.32 & 0.011 \\
\hline Neutrophil** & 4645 & $|8| 1$ & 2210 & 4330 & 10100 & 2088 & 8996 & 4156 & 2700 & 8450 & 24100 & 3880 & $<0.001$ \\
\hline Lymphocyte* & 2068 & 1053 & 300 & 1885 & 6700 & $1748-2388$ & 1746 & 1013 & 200 & 1600 & 5000 & $1465-1986$ & 0.124 \\
\hline Platelets* $\left(x \mid 0^{3}\right)$ & 269 & 74 & 88 & 259 & 431 & 246-291 & 252 & 81 & 111 & 235 & 456 & $235-281$ & 0.295 \\
\hline$N L R^{* *}$ & 2.92 & 2.3 & 0.45 & 2.23 & 12.94 & 1.7 & 7.33 & 5.95 & 1.6 & 5.77 & 31 & 7.19 & $<0.001$ \\
\hline Native Thiol* & 436.4 & 65.2 & 278.4 & 436.2 & 578.3 & $416.6-456.2$ & 352.1 & 109.1 & 93.5 & 342.6 & 710 & $332.9-392.2$ & $<0.001$ \\
\hline Disulphide* & 16.22 & 7.41 & 3.85 & 15.38 & 33 & $13.97-18.47$ & 21.39 & 14.55 & 0.45 & 19.58 & 71.1 & $17.43-25.75$ & 0.024 \\
\hline Total Thiol* & 468.8 & 65.1 & 305.5 & 470.9 & 607.3 & $449.0-488.6$ & 394.9 & 108.2 & 96.7 & 389.7 & 735.7 & $376.9-434.6$ & $<0.001$ \\
\hline Index I & 0.038 & 0.018 & 0.008 & 0.039 & 0.073 & 0.026 & 0.068 & 0.058 & 0.001 & 0.055 & 0.273 & 0.039 & 0.005 \\
\hline Index $2^{\text {** }}$ & 0.035 & 0.016 & 0.008 & 0.036 & 0.064 & 0.022 & 0.056 & 0.039 & 0.001 & 0.049 & 0.177 & 0.032 & 0.005 \\
\hline Index $3^{* *}$ & 0.930 & 0.031 & 0.872 & 0.929 & 0.984 & 0.044 & 0.888 & 0.079 & 0.647 & 0.901 & 0.998 & 0.064 & 0.005 \\
\hline IMA $^{* *}$ & 66.7 & 9.4 & 50.8 & 70.5 & 84 & 18.1 & 73.7 & 9.3 & 35.8 & 74 & 97 & 6.8 & $<0.001$ \\
\hline Ferroksidaz & 567 & 185.8 & 309.7 & 514.6 & 1054.1 & 255.1 & 461.5 & 224.2 & 40 & 472.5 & 1247.7 & 184 & 0.025 \\
\hline
\end{tabular}

*Independent Samples-t test; Mean \pm SD ve $95 \%$ Cl. **Mann Whitnet-U test; Median (Min-Max) ve IQR.

NLR: Neutrophil lymphocyte ratio; IMA: Ischemia-modified albumin; SD: Standard deviation; Min: Minimum; Max: Maximum; CI: Confidence interval; IQR: Interquartile interval. Indexl: disulphide/native thiol. Index2: disulphide/total thiol. Index3: native thiol/total thiol. 


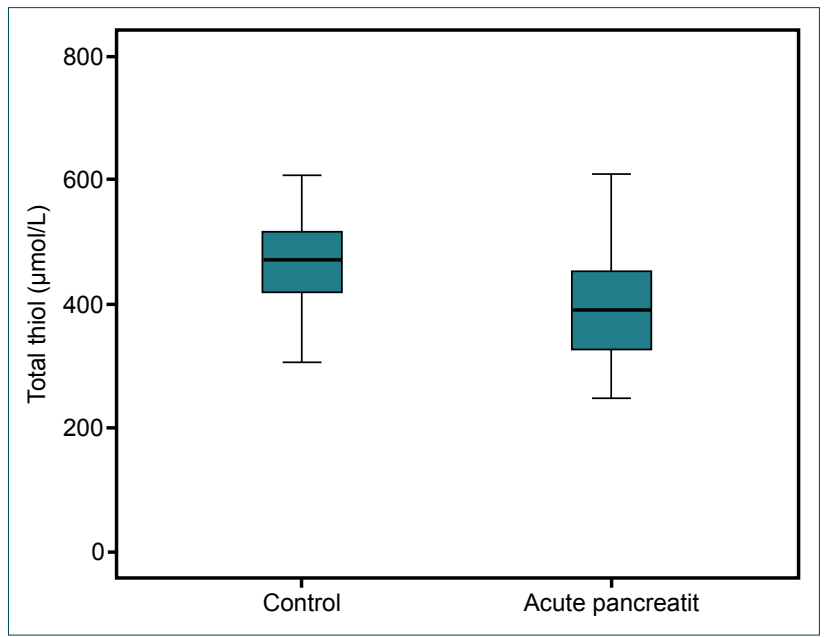

Figure 1. The total thiol distribution in the patient and control group.

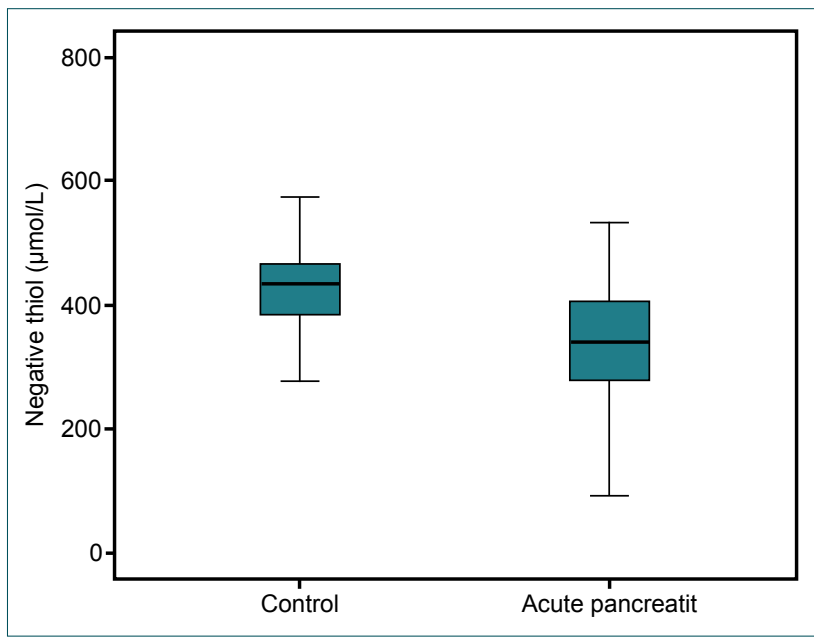

Figure 2. The native thiol distribution in the patient and control group.

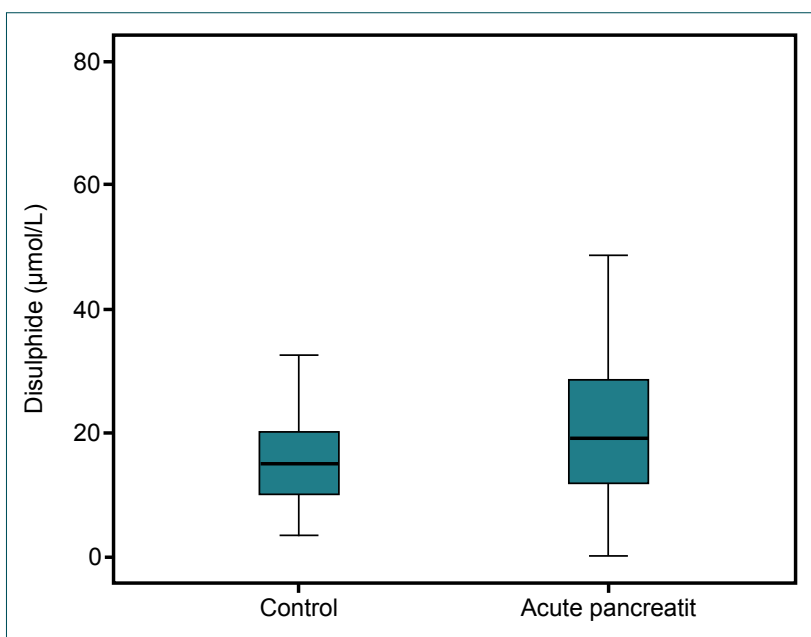

Figure 3. The disulphide distribution in the patient and control group

\section{DISCUSSION}

The dynamic thiol/disulphide homeostasis has a crucial significance in detoxification, antioxidant protection, apoptosis, signal transduction, regulation of enzymatic activity, as well as transcription factors and cellular signaling mechanisms. ${ }^{[3,4]}$ Since thiols have continuous interaction with almost all of the physiological oxidants, they are essential antioxidant buffers. $[15,16]$ Thiol protein groups constitute a significant antioxidant group and are responsible for $52.9 \%$ of the total serum antioxidant capacity in healthy people. ${ }^{[17]} \mathrm{A}$ new and automated testing system was proposed by Erel and Neselioglu ${ }^{[5]}$ to determine the dynamic thiol/disulphide homeostasis. Total serum thiol and native thiol levels are measured; and disulphide concentrations are computed in this method. This test shows the changes in favor of the thiol or disulphide.

Acute pancreatitis is a fascinating disease. The two most common etiologies of acute pancreatitis are gallstones and excessive alcohol consumption. The diagnosis of acute pancreatitis is made with a combination of history, physical examination, computed tomography scan, and laboratory evaluation. Differentiating patients who will have a benign course of their pancreatitis from patients who will have severe pancreatitis is challenging to the clinician.

Releasing active pancreatic enzymes into the bloodstream initiates an inflammatory cascade, which is involved in stimulating the production of many inflammatory cytokines, including interleukins and tumor necrosis factor- $\alpha$. This cytokine storm can be determined by several serum markers. C-reactive protein (CRP) is the most widely studied and used serum marker to assess the severity of AP. Aside from CRP, many other acute-phase reactants and inflammatory markers, including cytokines, have been studied to assess the severity of AP. Recently, several studies investigated the thiol-disulphide and IMA levels in disorders in which oxidative stress plays an important role in the pathogenesis, including diabetes, cirrhosis, end-stage renal disease, sepsis, and inflammatory bowel disease. Ischemia and oxidative stress are the major determinants of forming IMA, and an increase in serum IMA levels was demonstrated in ischemic disorders and in disorders that oxidative stress contributes to its pathogenesis. Oxidative stress and the production of free radicals are responsible for the progression of pancreatic inflammation, and triggering the generation of inflammatory cytokines is the key event in the pathogenesis of acute pancreatitis. ${ }^{[18]}$

We concluded that thiol-disulphide levels decreased as oxidative stress increased in acute pancreatitis. This study aims to compare the thiol-disulphide homeostasis and other blood parameters levels of patients with AP and healthy controls, and to investigate thiol-disulphide homeostasis as a marker of disease severity.

In the present study, disulphide/total thiol and disulphide/native thiol rates increased in favor of disulphide at a significant level. However, the native thiol levels decreased. The thiol level, native thiol level, and native thiol/total thiol percent ratios were lower. 
The findings showed that in the thiol/disulphide homeostasis tests that the homeostasis shifted towards the thiol or disulphide side. When the novel method was used, low thiol/ disulphide homeostasis was detected in some clinical settings (such as hyperemesis gravidarum, acute myocardial infarction, non-ST elevation myocardial infarction, and Type I Diabetes Mellitus). ${ }^{[15,19-21]}$

Reduced glutathione is the basic non-protein thiol in the cells of all mammals and constitutes a significant antioxidant. In animal AP models, its decrease in pancreatic tissue was shown in previous studies. ${ }^{[22-24]}$ In thiol measurements, these studies employed pancreatic tissue; however, in our study, the thiol/ disulphide homeostasis parameters were measured in serum with a novel, easy and full-automatic method in AP patients. The low-molecular-weight thiols and disulphides were evaluated in a study conducted on animal models with AP by Moreno et al., ${ }^{[25]}$ who considered disulphide stress as a specific OS type that was associated with mixed disulphides, especially protein cysteinylation, and oxidation of thiols like gamma-glutamylcysteine, cysteine, and homocysteine. However, they did not report any glutathione oxidation or changes in protein glutathionylation. It was also determined that reduced glutathione level reduced in the pancreatic tissue of rats with AP. ${ }^{[25]}$

Thiol levels were investigated in studies conducted on animals with pancreatitis, and the thiol-disulphide homeostasis parameters have been examined in humans for the past few years. In our study, the disulphide/total thiol and disulphide/ native the thiol rates increased at a significant level in favor of disulphide. However, the native thiol and total thiol levels decreased. The thiol-disulphide homeostasis increased in favor of disulphide. Similar results were obtained in a study that was conducted before ours. ${ }^{[26]}$

In our study, we obtained similar results with different tests that showed oxidative stress in tissues. There are several other studies that examined plasma oxidative stress. ${ }^{[25,27,28]}$ We determined that this homeostasis shifted in favor of disulphide by examining the thiol-disulphide homeostasis in AP.

Among OS markers, there are ischemia-modified albumin, protein carbonyls and superoxide dismutase, which increase among AP in different trials. ${ }^{[27-29]}$ In a recent meta-analysis study, it was reported that antioxidant therapy had possible benefits for $A P$, which might be considered as a proof that decreases in the antioxidant levels occurring in AP pathogenesis. ${ }^{[30,31]}$

The neutrophil lymphocyte ratio, which is examined in the serum, may be considered as an indirect indicator of the immune response capacity of the host. The reason why NLR indicates that the prognosis is bad may be due to that tumors make metastasis through cytokines and chemokines, and that the mechanism in which the dominance of neutrophils may suppress the cytotoxic T cells. In the first 48 hours, the increase in the NLR is related to severe acute pancreatitis and is an independent negative prognostic marker in $\mathrm{AP}^{[32]}$ In the present study, we could not detect any statistically significant relation between the blood thiol-disulphide homeostasis parameters and serum NLR.

The findings suggest the thiol/disulphide homeostasis deficiency may have a role in the AP pathogenesis. Complementing with thiol compounds like N-Acetyl Cysteine (NAC) may be a target for AP therapy. NAC is considered as a free radical collector and stimulates the glutathione synthesis. ${ }^{[30,31]}$ In the study, the findings suggest that mixed antioxidant supplementation with NAC could reduce the hospital stay and the rate of complications in AP patients. ${ }^{[33,34]}$

\section{Conclusion}

The disruption of thiol-disulphide homeostasis may have a role in the pathogenesis of acute pancreatitis. Since the thiol level is decreased, administering complementary treatment for thiol deficiency may contribute to the healing of the disease.

Ethics Committee Approval: Approved by the local ethics committee (date: 03.12.2014, no: 208).

Peer-review: Internally peer-reviewed.

Authorship Contributions: Concept: F.G.E.H., Y.O.; Design: G.P.G., A.Ş.; Supervision: Ö.E.; Fundings: Ö.E.; Materials: F.G.E.H., Y.O.; Data: F.G.E.H., Y.O.; Analysis: F.G.E.H., Y.O., A.Ş.; Literature search: T.A.T., P.B.; Writing: F.G.E.H., Y.O. ; Critical revision: F.G.E.H., Y.O., F.I.

\section{Conflict of Interest: None declared.}

Financial Disclosure: The autors declared that this study has received no financial support.

\section{REFERENCES}

1. Sen CK, Packer L.Thiol homeostasis and supplements in physical exercise. Am J Clin Nutr 2000;72:653-69. [CrossRef]

2. Turell L, Radi R, Alvarez B. The thiol pool in human plasma: the central contribution of albumin to redox processes. Free Radic Biol Med 2013;65:244-53. [CrossRef]

3. Biswas S, Chida AS, Rahman I. Redox modifications of protein-thiols: emerging roles in cell signaling. Biochem Pharmacol 2006;71:551-64.

4. Circu ML, Aw TY. Reactive oxygen species, cellular redox systems, and apoptosis. Free Radic Biol Med 2010;48:749-62. [CrossRef]

5. Erel O, Neselioglu S. A novel and automated assay for thiol/disulphide homeostasis. Clin Biochem 2014;47:326-32. [CrossRef]

6. Ellman G, Lysko H. A precise method for the determination of whole blood and plasma sulfhydryl groups. Anal Biochem 1979;93:98-102.

7. Tenner S, Baillie J, DeWitt J, Vege SS; American College of Gastroenterology. American College of Gastroenterology guideline management of acute pancreatitis. Am J Gastroenterol 2013;108:1400-15. [CrossRef]

8. Hamada T, Yasunaga H, Nakai Y, Isayama H, Horiguchi H, Fushimi K, et al. Japanese severity score for acute pancreatitis well predicts in-hospital mortality: a nationwide survey of 17,901 cases. J Gastroenterol 2013;48:1384-91.

9. Banks PA, Bollen TL, Dervenis C, Gooszen HG, Johnson CD, Sarr MG, et al; Acute Pancreatitis Classification Working Group. Classification of acute pancreatitis--2012: revision of the Atlanta classification and defini- 
tions by international consensus. Gut 2013;62:102-11. [CrossRef]

10. Chen Y, Ke L, Tong Z, Li W, Li J. Association between severity and the determinant-based classification, Atlanta 2012 and Atlanta 1992, in acute pancreatitis: a clinical retrospective study. Medicine (Baltimore) 2015;94:e638.

11. Vege SS, Gardner TB, Chari ST, Munukuti P, Pearson RK, Clain JE, et al. Low mortality and high morbidity in severe acute pancreatitis without organ failure: a case for revising the Atlanta classification to include "moderately severe acute pancreatitis".Am J Gastroenterol 2009;104:710-5.

12. Bar-Or D, Lau E, Winkler JV. A novel assay for cobalt-albumin binding and its potential as a marker for myocardial ischemia-a preliminary report. J Emerg Med 2000;19:311-5. [CrossRef]

13. Erel O. Automated measurement of serum ferroxidase activity. Clin Chem 1998;44:2313-9.

14. Balthazar EJ, Robinson DL, Megibow AJ, Ranson JH. Acute pancreatitis: value of CT in establishing prognosis. Radiology 1990;174:331-6.

15. Ergin M, Cendek BD, Neselioglu S, Avsar AF, Erel O. Dynamic thiol-disulfide homeostasis in hyperemesis gravidarum. J Perinatol 2015;35:789-92. [CrossRef]

16. Otal Y, Demircan S, Şener A, Alışık M, Tanrıverdi F, Ercan Haydar FG, et al. Acute Renal Failure and Thiol-Disulfide Homeostasis. J Nephrol Ther 2018;8:312. [CrossRef]

17. Erel O. A novel automated direct measurement method for total antioxidant capacity using a new generation, more stable ABTS radical cation. Clin Biochem 2004;37:277-85. [CrossRef]

18. Sahin A, Turkoglu S, Tunc N, Duzenci D, Solmaz OA, Bahcecioglu IH, et al. Is ischemia-modified albumin a reliable tool for the assessment of acute pancreatitis? Ther Clin Risk Manag 2018;14:627-35. [CrossRef]

19. Kundi H, Ates I, Kiziltunc E, Cetin M, Cicekcioglu H, Neselioglu S, et al. A novel oxidative stress marker in acute myocardial infarction; thiol/ disulphide homeostasis. Am J Emerg Med 2015;33:1567-71. [CrossRef]

20. Kundi H, Erel Ö, Balun A, Çiçekçioğlu H, Cetin M, Kiziltunç E, et al. Association of thiol/disulfide ratio with syntax score in patients with NSTEMI. Scand Cardiovasc J 2015;49:95-100. [CrossRef]

21. Ates I, Kaplan M, Yuksel M, Mese D, Alisik M, Erel Ö, et al. Determination of thiol/disulphide homeostasis in type 1 diabetes mellitus and the factors associated with thiol oxidation. Endocrine 2016;51:47-51.

22. Perez S, Pereda J, Sabater L, Sastre J. Redox signaling in acute pancreati- tis. Redox Biol 2015;5:1-14. [CrossRef]

23. Dabrowski A, Chwiećko M. Oxygen radicals mediate depletion of pancreatic sulfliydryl compounds in rats with cerulein-induced acute pancreatitis. Digestion 1990:47:15-9. [CrossRef]

24. Schoenberg MH, Büchler M, Gaspar M, Stinner A, Younes M, Melzner I, et al. Oxygen free radicals in acute pancreatitis of the rat. Gut 1990;31:1138-43.

25. Moreno ML, Escobar J, Izquierdo-Álvarez A, Gil A, Pérez S, Pereda J, et al. Disulfide stress: a novel type of oxidative stress in acute pancreatitis. Free Radic Biol Med 2014;70:265-77. [CrossRef]

26. Köseoğlu H, Alışık M, Başaran M, Tayfur Yürekli Ö, Solakoğlu T, Tahtac1 M, et al. Dynamic thiol/disulphide homeostasis in acute pancreatitis. Turk J Gastroenterol 2018;29:348-53.

27. Dur A, Kocaman O, Kocyiğit A, Turkdogan KA, Sonmez E, Keskin S, et al. Oxidative status and lymphocyte DNA damage in patients with acute pancreatitis and its relationship with severity of acute pancreatitis. Turk J Gastroenterol 2016;21:68-72. [CrossRef]

28. Baser H, Can U, Karasoy D, Ay AS, Baser S, Yerlikaya FH, et al. Evaluation of oxidant/anti-oxidants status in patients with mild acute -pancreatitis. Acta Gastroenterol Belg 2016;79:23-8.

29. Winterbourn CC, Bonham MJ, Buss H, Abu-Zidan FM, Windsor JA. Elevated protein carbonyls as plasma markers of oxidative stress in acute pancreatitis. Pancreatology 2003;3:375-82. [CrossRef]

30. Thareja S, Bhardwaj P, Sateesh J, Saraya A. Variations in the levels of oxidative stress and antioxidants during early acute pancreatitis. Trop Gastroenterol 2009;30:26-31.

31. Jeurnink SM, Nijs MM, Prins HA, Greving JP, Siersema PD. Antioxidants as a treatment for acute pancreatitis: A meta-analysis. Pancreatology 2015;15:203-8. [CrossRef]

32. Binnetoğlu E, Akbal E, Güneş F, Sen $H$. The prognostic value of neutrophil-lymphocyte ratio in acute pancreatitis is controversial. J Gastrointest Surg 2014;18:885. [CrossRef]

33. Du BQ, Yang YM, Chen YH, Liu XB, Mai G. N-acetylcysteine improves pancreatic microcirculation and alleviates the severity of acute necrotizing pancreatitis. Gut Liver 2013;7:357-62. [CrossRef]

34. Katsinelos P, Kountouras J, Paroutoglou G, Beltsis A, Mimidis K, Zavos C. Intravenous $\mathrm{N}$-acetylcysteine does not prevent post-ERCP pancreatitis. Gastrointest Endosc 2005;62:105-11. [CrossRef]

\title{
ORIJINAL ÇALIŞMA - ÖZET
}

\section{Akut pankreatitli hastalarda tiyol-disülfit dengesi ve diğer kan parametreleri ile ilişkisi \\ Dr. Fadime Güllü Ercan Haydar, ${ }^{1}$ Dr. Yavuz Otal, ${ }^{2}$ Dr. Alp Şener, ${ }^{2}$ Dr. Gül Pamukçu Günaydın, ${ }^{2}$ \\ Dr. Ferhat İçme, ${ }^{2}$ Dr. Tuğba Atmaca Temrel, ${ }^{2}$ Dr. Pervin Baran, ${ }^{3}$ Dr. Özcan Erel ${ }^{4}$}

\author{
${ }^{1}$ Atatürk Eğitim ve Araștırma Hastenisi, Genel Cerrahi Kliniği, Ankara \\ ${ }^{2}$ Atatürk Eğitim ve Araştırma Hastanesi, Acil Tıp Kliniği, Ankara \\ ${ }^{3}$ Atatürk Eğitim ve Araştırma Hastanesi,Tıbbi Biyokimya Kliniği, Ankara \\ ${ }^{4}$ Yıldırım Beyazıt Üniversitesi Tıp Fakültesi, Tıbbi Biyokimya Anabilim Dalı, Ankara
}

AMAÇ: Akut pankreatit (AP) karın ağrısı nedeniyle acil serviste sıklıkla görülen bir hastalıktır. Bu çalışma AP tanısı konulan hastalarda, kanda tiyoldisülfit parametrelerinin ölçümü ve diğer kan parametreleri ile ilişkisinin değerlendirilmesi amaçlandı.

GEREÇ VE YÖNTEM: Çalışmaya acil servise başvuran 56 (\%56) hasta ve 44 (\%44) sağlıklı gönüllü olmak üzere toplam I 00 örnek alındı. Hastalardan geliş anında detaylı kan örnekleri alındı. Akut pankreatit tanıı konan hastaların başvurusu sırasında ki venöz kan örneklerinden Erel ve Neşelioğlu tarafından geliştirilen yepyeni bir yöntemle serumda tiyol-disülfide düzeyi çalışılı. Veriler bilgisayar ortamında değerlendirildi.

BULGULAR: Akut pankreatitin etiyolojisi 4 I hastada (\%73.2) safra taşı, bir hastada (\%। .7) hipertrigliseridemi, dört hastada (\% 7.I) alkol kullanımı ve 10 hastada (\% I7.8) idiyopatik idi. Kan tiyol düzeyleri düşük iken, disülfide düzeyleri anlamlı derecede yüksekti. Diğer kan parametreleri olan amilaz, lipaz, NLR (nötrofil lenfosit oranı) ile tiyol-disülfide dengesi parametreleri arasında istatistiki açıdan anlamlı fark bulunamadı.

TARTIŞMA: Akut pankreatit de patogenezde tiyol-disülfit dengesinin bozulması rol oynayabilir. AP'de kanda tiyol düzeyi azaldığından bu tiyol eksikliğini tamamlayıcı tedavilerin verilmesi hastalığın iyileşmesine katkıda bulunabilir.

Anahtar sözcükler: Akut pankreatit; oksidatif stres; tiyol-disülfid dengesi.

Ulus Travma Acil Cerrahi Derg 2020;26(I):37-42 doi: 10.14744/tjtes.2019.38969 